\title{
Surface Characteristics of Particleboard Produced from Hydro-thermally Treated Wheat Stalks
}

\author{
Ümit Büyüksarı ${ }^{\mathrm{a}, *}$ and Hüseyin Akkılıç ${ }^{\mathrm{b}}$ \\ Surface characteristics were studied for particleboards produced from \\ hydro-thermally treated (HTT) and non-treated (NT) wheat stalk (WS). \\ Wood and wheat stalk particles were used as experimental materials. The \\ wheat stalk particles were subjected to $\mathrm{HTT}$ at a temperature of $180^{\circ} \mathrm{C}$ for \\ 8 minutes in a steam explosion machine. HTT and NT WS particles were \\ added at $10 \%, 20 \%, 30 \%$, and $40 \%$ to the wood particles. The surface \\ roughness and wettability of the produced panels were determined. The \\ roughness measurements, average roughness $\left(R_{a}\right)$, maximum roughness \\ $\left(R_{\max }\right)$, and mean peak-to-valley height $\left(R_{z}\right)$ were performed using a fine \\ stylus tracing technique. The wetting behavior of the panels was \\ characterized by the contact angle method (goniometer technique). The \\ contact angle (CA) measurements were obtained by using a KSV Cam- \\ 101 Scientific Instrument connected with a digital camera and computer \\ system. Statistical analyses showed significant differences in the surface \\ roughness and wettability of the particleboards following hydro-thermal \\ modification. The addition of WS to the panels significantly decreased the \\ roughness values. However, all of the HTT groups exhibited higher \\ roughness compared to NT groups. The CA values decreased when the \\ WS content increased. The wettability of the particleboard containing HTT \\ WS particles was improved.
}

Keywords: Hydro-thermal treatment; Particleboard; Wheat stalks; Surface roughness; Wettability

Contact information: a: Department of Wood Mechanics and Technology, Düzce University, Düzce, Turkey; b: Department of Wood Mechanics and Technology, Istanbul University-Cerrahpaşa, İstanbul, Turkey; *Corresponding author: umitbuyuksari@duzce.edu.tr

\section{INTRODUCTION}

In Turkey, approximately 27 million tons of wheat stalk (WS) is produced annually. The WS is morphologically more complicated than wood. It contains a relatively large number of elements, including the actual fibers, parenchyma cells, vessel elements, and epidermal cells, which contain a high amount of ash and silica. The epidermal cells of the WS are the outermost surface cells that are covered by a thin wax layer. This layer deteriorates the moisture absorbance of WS's from water-based adhesives (Markessini et al. 1997; Hafezi and Hosseini 2014). The chemical composition of the WS is similar to wood; however, it has lower cellulose and higher hemicellulose and lignin quantities compared to wood (Markessini et al. 1997).

There are many research studies on the utilization of annual plants in the production of wood-based panels, such as particleboard and fiberboard (Turreda 1983; Yalınkılıç et al. 1998; Grigoriou et al. 2000; Nemli et al. 2001; Bektaş et al. 2002; Nemli et al. 2003; Mo et al. 2003; Güler and Özen 2004; Alma et al. 2005; Bektaş et al. 2005; Güler et al. 2006; Cöpür et al. 2007; Güler et al. 2008). Most studies reported that mechanical properties of the panels met the standard values while their physical properties (thickness 
swelling (TS) and water absorption (WA)) could not meet the standard value (Nemli et al. 2001; Bektaş et al. 2002; Nemli et al. 2003; Mo et al. 2003; Güler and Özen 2004; Alma et al. 2005; Bektaş et al. 2005; Güler et al. 2006; Cöpür et al. 2007; Güler et al. 2008). One of the most successful ways to increase water resistance of the wood and wood-based composites is thermal modification. Property changes of thermally-treated wood mainly depend on the modification of hemicelluloses, which contribute to the sorption of water. Dehydration due to reduction of free hydroxyl groups leads to decreased moisture uptake; an addition contribution to the decrease is the formation of hydrophobic substances due to cross-linkage reactions of the wood polymers (Tjeerdsma and Militz 2005). The thermal treatment also affects the surface properties of wood and wood composites (Petrissans et al. 2003; Sernek et al. 2004; Follrich et al. 2006; Gerardin et al. 2007; Ayrılmıs and Winandy 2009; Jarusombuti et al. 2010).

Many attempts have been made to improve the properties of wood composites via application of different treatments. Bekhta et al. (2013) evaluated some properties of particleboards manufactured from WS that were pretreated with acetic anhydride, soapy solution, hot water, and steam. They concluded that the pretreatment of WS improved physical and mechanical properties of particleboards. Bekhta et al. (2018) investigated the addition of ethanol to urea formaldehyde (UF) adhesive and boiling in soapy solution to improve the bonding quality of the wood-WS composites. The hydro-thermal treatment (HTT) can be alternative way to increase the bondability of wood and WS particles with UF resin removing the thin wax layer of the WS. The objectives of this study were to investigate the surface roughness and wettability of particleboards produced from hydrothermally treated WS's and to increase the use of annual plants in the production of wood based panels.

\section{EXPERIMENTAL}

\section{Materials}

Industrial wood particles (pine and beech) and the WS were used as experimental materials in this study. The industrial wood particles were supplied from a commercial particleboard plant in Kocaeli/Turkey, and WS's were harvested from Duzce in the Black Sea region of Turkey. The WS's were chipped and classified for core layer (CL) and surface layer (SL) particles. The particles that remained in the ranges 3 to $1.5 \mathrm{~mm}$ and 1.5 to $0.8 \mathrm{~mm}$, as separated by sieves, were utilized in the CL and SL of the particleboards, respectively. The particles were dried at $100{ }^{\circ} \mathrm{C}$ temperature in a technical oven to reach target $3 \%$ moisture content. The HTT was applied to WS particles in a steam explosion machine at $180{ }^{\circ} \mathrm{C}$ temperature for 8 min (Fig. 1).

The particleboards were produced under laboratory conditions (Fig. 2). The target density was $600 \mathrm{~kg} . \mathrm{m}^{-3}$. The panels were design to consist of $35 \%$ particles at the SL and $65 \%$ at the CL. The control group contained $100 \%$ industrial wood particles. The HTT and non-treated (NT) WS particles were added from $10 \%$ to $40 \%$ to the particleboards.

The UF resin at $55 \%$ solid content and 1.25 formaldehyde/urea mole ratio was used at $8 \%$ for CL and $10 \%$ for SL based on the oven dry weight of particles. One-percent ammonium chloride (concentration 20\%) solution was added to the UF resin as a hardener based on the solid adhesive amount. The CL and SL particles were separately placed in a drum blender and sprayed with UF resin and hardener for $8 \mathrm{~min}$ to obtain homogenized mixture. The particleboards were pressed in a hot press using a pressure of $2.6 \mathrm{MPa}$ and a 
temperature of $150{ }^{\circ} \mathrm{C}$ for $7 \mathrm{~min}$. The panels were conditioned in a climate chamber for three weeks before the tests. The experimental design is shown in Table 1.

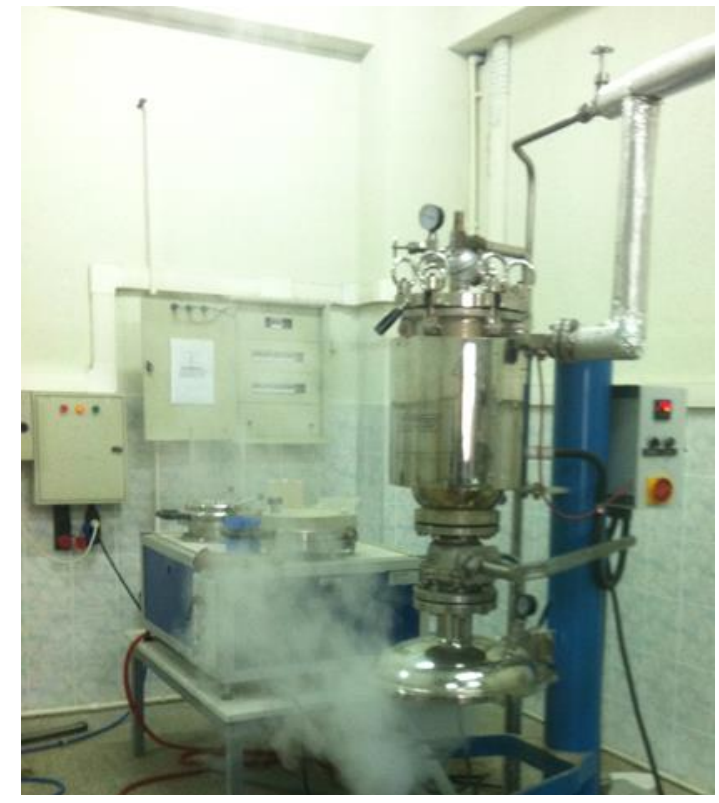

Fig. 1. HHT application to the WS particles in the steam explosion machine

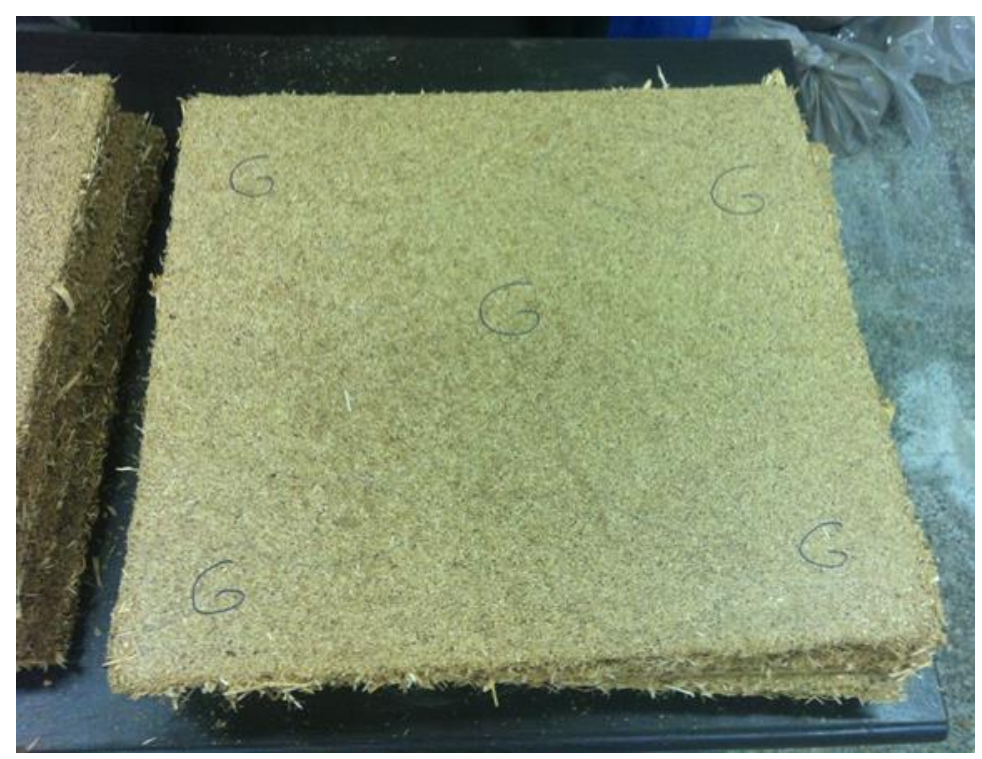

Fig. 2. The particleboards produced from HTT and NT WSwood particles

Table 1. Experimental Design

\begin{tabular}{|c|c|c|c|c|c|}
\hline Board Type & Method & $\begin{array}{c}\text { Temperature } \\
\left({ }^{\circ} \mathrm{C}\right)\end{array}$ & $\begin{array}{l}\text { Time } \\
\text { (min) }\end{array}$ & $\begin{array}{c}\text { Wheat Stalk } \\
\text { Ratio (\%) }\end{array}$ & $\begin{array}{c}\text { Wood Particle } \\
\text { Ratio (\%) }\end{array}$ \\
\hline Control & $\begin{array}{c}\text { Non- } \\
\text { treated }\end{array}$ & - & - & 0 & 100 \\
\hline HTT-10 & \multirow{4}{*}{$\begin{array}{l}\text { Hydro- } \\
\text { thermally } \\
\text { treated }\end{array}$} & \multirow{4}{*}{180} & \multirow{4}{*}{8} & 10 & 90 \\
\hline HTT-20 & & & & 20 & 80 \\
\hline HTT-30 & & & & 30 & 70 \\
\hline HTT-40 & & & & 40 & 60 \\
\hline NT-10 & \multirow{4}{*}{$\begin{array}{l}\text { Non- } \\
\text { treated }\end{array}$} & \multirow{4}{*}{ - } & \multirow{4}{*}{ - } & 10 & 90 \\
\hline NT-20 & & & & 20 & 80 \\
\hline NT-30 & & & & 30 & 70 \\
\hline NT-40 & & & & 40 & 60 \\
\hline
\end{tabular}

\section{Methods}

Determination of surface roughness

Twenty samples with a size of $50 \mathrm{~mm} \times 50 \mathrm{~mm}$ were cut from each type panel for the surface roughness (SR) measurements. All samples were conditioned in a climate chamber with a relative humidity of $65 \%$ and temperature of $20{ }^{\circ} \mathrm{C}$ until they attained $12 \%$ equilibrium moisture content prior to measurements. The measurement points were randomly marked on the sample surfaces, and the measurements were accomplished with a Mitutoyo SJ-301 surface roughness tester (Fig. 3). In this study, average roughness $\left(R_{a}\right)$, mean peak-to-valley height $\left(R_{z}\right)$, and maximum roughness $\left(R_{\max }\right)$ were used to evaluate the SR characterization according to ISO 4287 (1997) standard. 


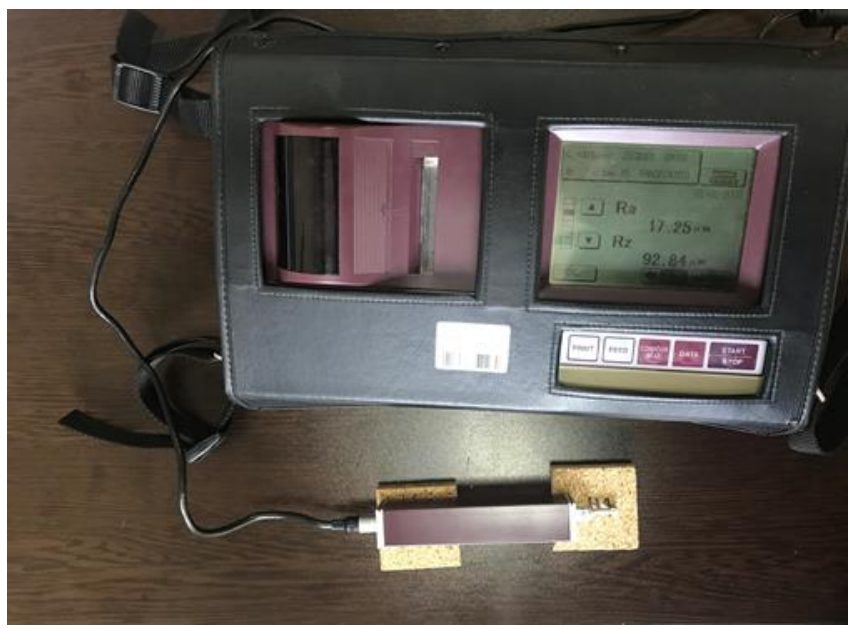

Fig. 3. The surface roughness measurement of the particleboards

\section{Determination of wettability}

The contact angle (CA) method was used to evaluate the wettability of the produced panels. The SR measurement samples were also used for the CA measurements. The CA values were obtained by using sessile drop method with an imaging system (KSV Cam101 Instrument, Finland). The image was captured immediately after the droplet of distilled water was placed on the surface, and then every 1 second for the duration 60 seconds.

\section{Data analyses and statistical methods}

For the surface roughness and wettability, all multiple comparisons were first subjected to an analysis of variance (ANOVA) at $\mathrm{p}<0.01$. Significant differences between mean values of the panel groups were determined using Duncan's multiple range test.

\section{RESULTS AND DISCUSSION}

Table 2 lists some statistical parameters of the average roughness $\left(R_{a}\right)$ and Duncan's multiple range test results of the produced particleboards.

Table 2. Average Roughness and Duncan's Test Results of the Produced Panels

\begin{tabular}{|c|c|c|c|c|c|c|c|c|}
\hline Property & Panel Type & $N$ & $X(\mu \mathrm{m})$ & SD & SE & $X_{\min }(\mu \mathrm{m})$ & $X_{\max }(\mu \mathrm{m})$ & $\mathrm{C}_{\mathrm{v}}(\%)$ \\
\hline \multirow{9}{*}{$R_{a}(\mu \mathrm{m})$} & Control & 40 & $21.1 \mathrm{~A}$ & 4.7 & 0.8 & 12.3 & 33.1 & 22.5 \\
\hline & HTT-10 & 40 & $21.1 \mathrm{~A}$ & 4.7 & 0.7 & 12.7 & 30.7 & 22.2 \\
\hline & HTT-20 & 40 & $18.5 \mathrm{BC}$ & 5.1 & 0.8 & 9.5 & 35.7 & 27.4 \\
\hline & HTT-30 & 40 & $19.8 \mathrm{AB}$ & 4.2 & 0.7 & 9.8 & 28.7 & 21.0 \\
\hline & HTT-40 & 40 & 17.1 CD & 5.5 & 0.9 & 7.2 & 28.6 & 32.0 \\
\hline & NT-10 & 40 & $20.3 \mathrm{AB}$ & 4.1 & 0.6 & 11.7 & 30.7 & 20.1 \\
\hline & NT-20 & 40 & $15.9 \mathrm{D}$ & 3.9 & 0.6 & 8.2 & 23.5 & 24.4 \\
\hline & NT-30 & 40 & $15.3 \mathrm{D}$ & 4.1 & 0.6 & 7.6 & 26.4 & 26.7 \\
\hline & NT-40 & 39 & $16.0 \mathrm{D}$ & 3.6 & 0.6 & 8.9 & 25.0 & 22.5 \\
\hline
\end{tabular}

$N$ : number of specimens, $X$ : average, SD: standard deviation, SE: standard error, $X_{\min }$ : minimum value, $X_{\max }$ : maximum value, $\mathrm{C}_{\mathrm{v}}$ : coefficient of variation. Groups with identical capital letters in a column indicate that there is no statistical difference $(p<0.05)$ between the samples according to Duncan's multiple range test. 
The control group made from 100\% wood particles had the highest average roughness value of $21.1 \mu \mathrm{m}$, while the lowest average roughness $(15.3 \mu \mathrm{m})$ was observed for the particleboards containing 30\% NT WS particle in the mixture. Büyüksarı et al. (2010) determined that the $R_{\mathrm{a}}$ value of particleboards produced from $100 \%$ wood particles was $9.77 \mu \mathrm{m}$. The differences could be arise from raw material characteristics, species, particle size, shelling ratio, manufacturing variables, press parameters, resin content, and sanding process of the particleboards (Hiziroglu et al. 2008). The addition of WS to the particleboards significantly improved the average roughness values. This can clearly be observed by inspection of raw data from SR profilometer that recorded noticeably shallower ridges and valleys compared to control panels (Fig. 4). Similar improvements were also observed by Hafezi and Hosseini (2014). They found that the particleboards produced from 100\% WS particles had the smoothest surface compared to particleboards containing poplar particles in the $0 \%$ silane level. Nemli et al. (2005) stated that raw material type and characteristics affected the surface roughness of particleboards. The improvement of the surface roughness of the produced particleboards was most likely because of the morphological properties of wood and WS. The WS is morphologically more complicated than wood. It contains a relatively large number of elements, including the actual fibers, parenchyma cells, vessel elements, and epidermal cells, which contain a high amount of ash and silica (Markessini et al. 1997; Hafezi and Hosseini 2014). Also, the WS has lower cellulose and higher hemicellulose and lignin quantities compared to wood (Markessini et al. 1997).

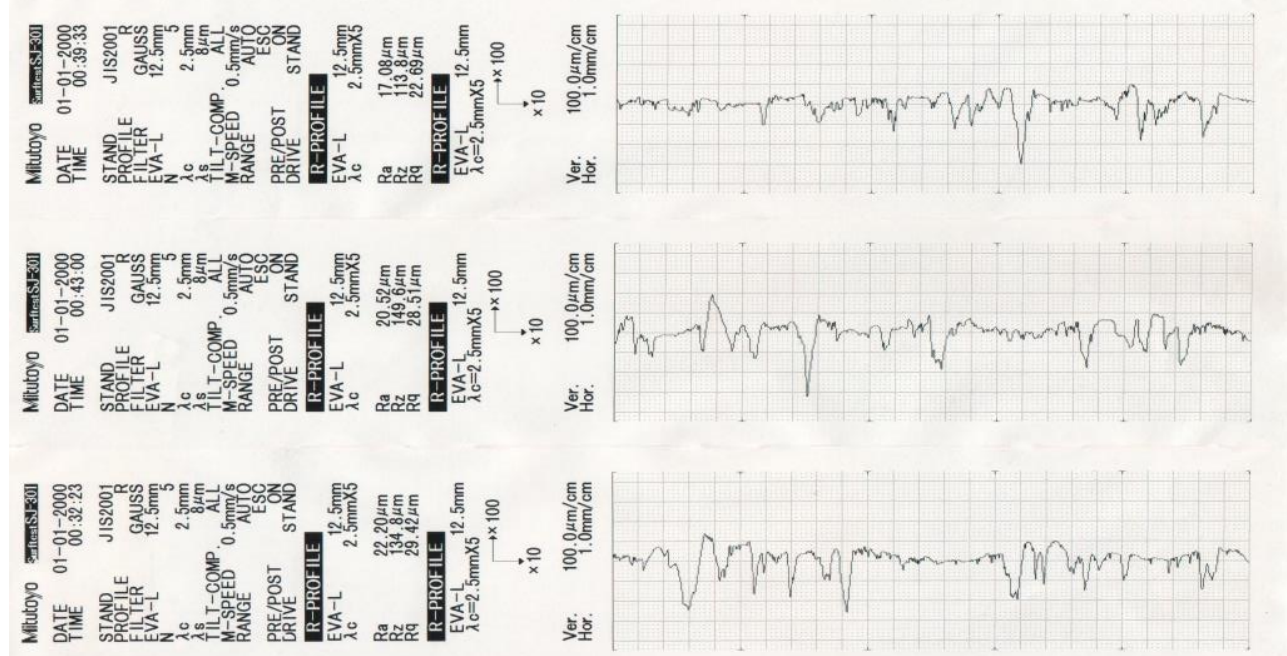

Fig. 4. Typical surface roughness profiles of some produced particleboards. NT-30 (Upper), HTT30 (Middle), and control (bottom)

All of the HTT groups exhibited higher average roughness values compared to NT groups (Fig. 5). However, this difference was not significant for the groups containing 10\% HTT and NT WS particles. Candan et al. (2012) concluded that the thermal modification process significantly affected the surface roughness values of the plywood panels. It was reported that the surface roughness of the plywood panels improved with increasing thermal treatment temperature up to $170{ }^{\circ} \mathrm{C}$ but the roughness value increased as modification temperature increased to $190{ }^{\circ} \mathrm{C}$. Yasar et al. (2020) observed a continuous decrease in the surface roughness value of the particleboards produced from $100 \%$ pine particles due to the increase of the heat treatment temperature from $120{ }^{\circ} \mathrm{C}$ to $180{ }^{\circ} \mathrm{C}$. In 
another study, Jarusombuti et al. (2010) determined that the MDF panels produced from thermally treated rubberwood fibers had smoother surface than that of NT fibers. They found that the MDF panels treated at $180{ }^{\circ} \mathrm{C}$ for $30 \mathrm{~min}$ had the smoothest surface with an $R_{\mathrm{a}}$ value of $4.02 \mu \mathrm{m}$, while the roughest surface was observed for the MDF panels containing $100 \%$ NT rubberwood fibers with an $R_{\mathrm{a}}$ value of $6.93 \mu \mathrm{m}$.

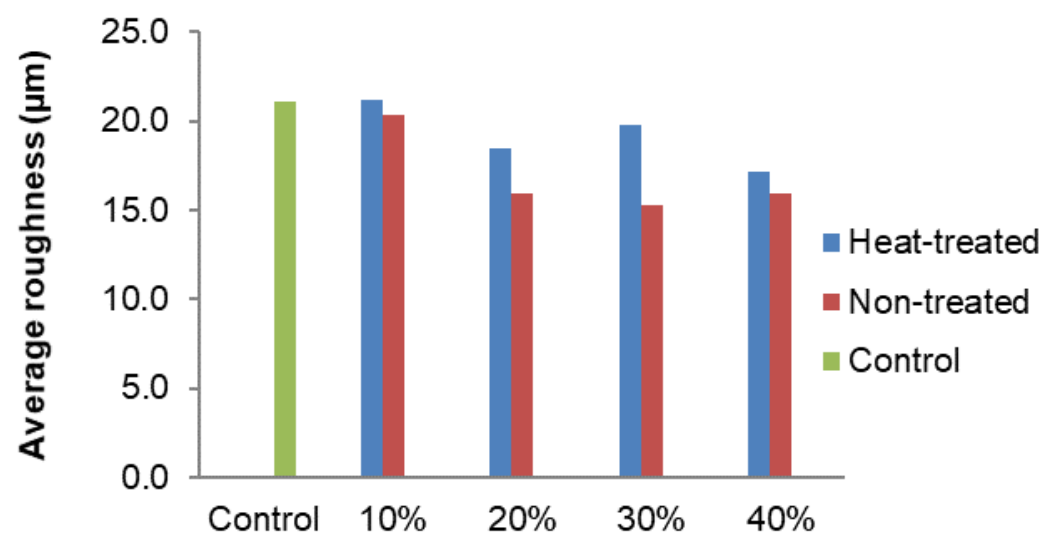

Fig. 5. The average roughness values of the particleboards produced from HTT and NT WS particles

In the NT panels, the average roughness value of the panels decreased with increasing WS content in the panels (Fig. 5). The NT-10 (containing 10\% WS) had the highest roughness value, while the NT-30 (containing 30\% WS) had the smoothest surface. The NT-30 exhibited $27.5 \%$ and $24.6 \%$ lower average roughness value compared to the control and NT-10 groups, respectively. Şahin et al. (2018) determined that all surface roughness parameters were decreased due to the increase of the use of rice husks in the particleboard. Güler (2019) concluded that the surface roughness values decreased with increasing of canola particles ratio in the particleboards. It was found that the $R$ a values were $15.10 \mu \mathrm{m}$ and $5.11 \mu \mathrm{m}$ for the particleboards produced from $100 \%$ pine particles and $100 \%$ canola particles, respectively. On the contrary, Büyüksarı et al. (2010) found that the increase in pine cone ratio up to $50 \%$ in the particleboard resulted in higher $R_{\text {a value. The }}$ particleboards containing $50 \%$ pine cone had $58.7 \%$ higher $R_{\text {a value compared to control }}$ group. These decreases and increases in the average roughness values of the current study and previous studies can be attributed to differences in morphological and chemical characteristics of the WS, rice husk, canola, and pine cone. In the HTT panels, similar to the NT panels, the panel surfaces became smoother as the WS content increased. HTT-10 had the roughest surface with the value of $21.1 \mu \mathrm{m}$ and HTT-40 had the smoothest surface. The HTT-40 had 19.0\% lower roughness value than those of the control and HTT-10 groups.

Table 3 lists some statistical parameters of the maximum roughness $\left(R_{\max }\right)$ and Duncan's multiple range test results of the produced particleboards.

Similar trends were found for the maximum roughness values. The addition of WS to the panels significantly affected the $R_{\max }$ values. Büyüksarı et al. (2010) determined that the $R_{\max }$ value of particleboards produced from $100 \%$ wood particles was $52.77 \mu \mathrm{m}$. All of the HTT groups had greater maximum roughness compared to NT groups. This difference was statistically significant for the groups containing $30 \%$ and $40 \%$ WS particles. The NT- 
30 showed a $17.0 \%$ lower maximum roughness value compared to NT-10. In the HTT panels, the maximum roughness was found to be the highest in the HTT-30 group, while HTT-40 had the lowest value. The HTT-40 had 7.6\% and $6.7 \%$ lower maximum roughness value compared to HTT-30 and HTT-10, respectively. Jarusombuti et al. (2010) showed that the MDF panels produced from thermally treated rubberwood fibers had lower $R_{\max }$ values compared to control group. They found that the $R_{\max }$ value of the control and treated at $180{ }^{\circ} \mathrm{C}$ for $30 \mathrm{~min}$ were $52.08 \mu \mathrm{m}$ and $38.56 \mu \mathrm{m}$, respectively.

Table 3. Maximum Roughness and Duncan's Test Results of the Produced Panels

\begin{tabular}{|c|c|c|c|c|c|c|c|c|}
\hline Property & $\begin{array}{c}\text { Panel } \\
\text { Type }\end{array}$ & $N$ & $X(\mu \mathrm{m})$ & SD & SE & $X_{\min }(\mu \mathrm{m})$ & $X_{\max }(\mu \mathrm{m})$ & $\mathrm{C}_{\mathrm{v}}(\%)$ \\
\hline \multirow{6}{*}{} & Control & 40 & $177.5 \mathrm{~A}$ & 31.9 & 5.0 & 104.0 & 261.9 & 18.0 \\
\cline { 2 - 9 } & HTT-10 & 40 & $180.0 \mathrm{~A}$ & 30.5 & 4.8 & 121.1 & 249.7 & 17.0 \\
\cline { 2 - 9 } & HTT-20 & 40 & $167.5 \mathrm{AB}$ & 29.2 & 4.6 & 107.8 & 262.7 & 17.4 \\
\cline { 2 - 9 } $\begin{array}{c}R_{\max } \\
(\mu \mathrm{m})\end{array}$ & HTT-30 & 40 & $181.8 \mathrm{~A}$ & 33.2 & 5.2 & 117.0 & 249.4 & 18.2 \\
\cline { 2 - 9 } & $\mathrm{HTT}-40$ & 40 & $167.9 \mathrm{AB}$ & 34.9 & 5.5 & 80.2 & 231.7 & 20.8 \\
\cline { 2 - 9 } & $\mathrm{NT}-10$ & 40 & $176.2 \mathrm{~A}$ & 37.0 & 5.8 & 97.4 & 242.3 & 21.0 \\
\cline { 2 - 9 } & $\mathrm{NT}-20$ & 40 & $158.1 \mathrm{BC}$ & 32.7 & 5.2 & 86.6 & 237.1 & 20.7 \\
\cline { 2 - 9 } & $\mathrm{NT}-30$ & 40 & $146.2 \mathrm{C}$ & 27.7 & 4.4 & 94.4 & 219.3 & 19.0 \\
\cline { 2 - 9 } & $\mathrm{NT}-40$ & 39 & $146.3 \mathrm{C}$ & 34.5 & 5.5 & 41.7 & 219.1 & 23.6 \\
\hline
\end{tabular}

$N$ : number of specimens, $X$ : average, SD: standard deviation, SE: standard error, $X_{\min }$ : minimum value, $X_{\max }$ : maximum value, $C_{v}$ : coefficient of variation. Groups with identical capital letters in a column indicate that there is no statistical difference $(p<0.05)$ between the samples according to Duncan's multiple range test.

The mean peak-to-valley height $\left(R_{\mathrm{z}}\right)$ values and Duncan's multiple range test results of the produced particleboards are shown in Table 4.

Table 4. Mean Peak-to-valley Height and Duncan's Test Results of the Produced Panels

\begin{tabular}{|c|c|c|c|c|c|c|c|c|}
\hline Property & $\begin{array}{c}\text { Panel } \\
\text { Type }\end{array}$ & $N$ & $X(\mu \mathrm{m})$ & $\mathrm{SD}$ & $\mathrm{SE}$ & $X_{\min }(\mu \mathrm{m})$ & $X_{\max }(\mu \mathrm{m})$ & $\mathrm{C}_{\mathrm{v}}(\%)$ \\
\hline \multirow{6}{*}{$R_{z}(\mu \mathrm{m})$} & Control & 40 & $132.7 \mathrm{~A}$ & 23.1 & 3.6 & 88.4 & 183.9 & 17.4 \\
\cline { 2 - 9 } & HTT-10 & 40 & $133.6 \mathrm{~A}$ & 21.8 & 3.4 & 95.7 & 194.6 & 16.3 \\
\cline { 2 - 9 } & HTT-20 & 40 & $123.0 \mathrm{AB}$ & 25.9 & 4.1 & 78.6 & 216.5 & 21.0 \\
\cline { 2 - 9 } & HTT-30 & 40 & $129.0 \mathrm{~A}$ & 24.4 & 3.9 & 65.7 & 182.6 & 18.9 \\
\cline { 2 - 9 } & HTT-40 & 40 & $115.1 \mathrm{BC}$ & 26.7 & 4.2 & 56.7 & 178.6 & 23.2 \\
\cline { 2 - 9 } & NT-10 & 40 & $129.5 \mathrm{~A}$ & 21.1 & 3.3 & 84.1 & 167.8 & 16.3 \\
\cline { 2 - 9 } & NT-20 & 40 & $107.7 \mathrm{CD}$ & 18.8 & 3.0 & 70.2 & 143.5 & 17.5 \\
\cline { 2 - 9 } & NT-30 & 40 & $102.1 \mathrm{D}$ & 18.9 & 3.0 & 60.9 & 148.2 & 18.5 \\
\cline { 2 - 9 } & NT-40 & 39 & $106.3 \mathrm{CD}$ & 23.7 & 3.8 & 23.5 & 142.2 & 22.3 \\
\hline
\end{tabular}

$N$ : number of specimens, $X$ : average, SD: standard deviation, SE: standard error, $X_{\min }$ : minimum value, $X_{\max }$ : maximum value, $C_{v}$ : coefficient of variation. Groups with identical capital letters in a column indicate that there is no statistical difference $(p<0.05)$ between the samples according to Duncan's multiple range test.

The control group had a higher $R_{\mathrm{z}}$ value compared to the groups containing WS particles except for HTT-10. The addition of WS to the panels significantly improved the 
$R_{\mathrm{Z}}$ values of the produced panels. Similar results were found by Hafezi and Hosseini (2014) for WS and by Şahin et al. (2018) for rice husk particleboards. Şahin et al. (2018) determined that the $R_{\mathrm{z}}$ values were $21.18 \mu \mathrm{m}$ and $15.78 \mu \mathrm{m}$ for the particleboards produced from $100 \%$ wood particles and containing $30 \%$ rice husk particles, respectively. On the contrary, it was found that the increase in pine cone ratio up to $50 \%$ in the particleboard resulted in higher $R_{\mathrm{Z}}$ value (Büyüksar1 et al. 2010). They stated that the $R_{\mathrm{Z}}$ values were $36.22 \mu \mathrm{m}$ and $60.96 \mu \mathrm{m}$ for the particleboards produced from $100 \%$ wood particles and containing 50\% pine cone particles, respectively. In the NT panels, the $R_{\mathrm{z}}$ value of the panels decreased with increasing WS content in the panels. The NT-10 had the highest $R_{\mathrm{z}}$, a value of $129.5 \mu \mathrm{m}$, while the NT-30 had the lowest $R_{\mathrm{z}}$ at $102.1 \mu \mathrm{m}$. The NT-30 exhibited an $R_{\mathrm{z}}$ value $21.2 \%$ lower than NT-10.

All of the HTT groups had higher $R_{\mathrm{z}}$ values compared to NT groups containing a similar percent of WS particles. However, this difference was not significant for the groups containing $10 \%$ and $40 \%$ WS. In the HTT panels, similar to the NT panels, the $R_{\mathrm{z}}$ value of the panels decreased as the WS content increased. HTT-10 had the highest $R_{\mathrm{z}}$ value and HTT-40 had the lowest $R_{z}$ value. The HTT-40 exhibited a $13.8 \%$ lower $R_{\mathrm{z}}$ value compared to HTT-10. Jarusombuti et al. (2010) showed that the MDF panels produced from thermally treated rubberwood fibers had significantly lower $R_{\mathrm{z}}$ values compared to control group. It was found that the $R_{\mathrm{z}}$ value of the control and treated at $180{ }^{\circ} \mathrm{C}$ for $30 \mathrm{~min}$ were $41.15 \mu \mathrm{m}$ and $28.06 \mu \mathrm{m}$, respectively.

Figure 6 indicates the CA values of the produced panels. The effect of HTT on the wettability of the panels was significant.

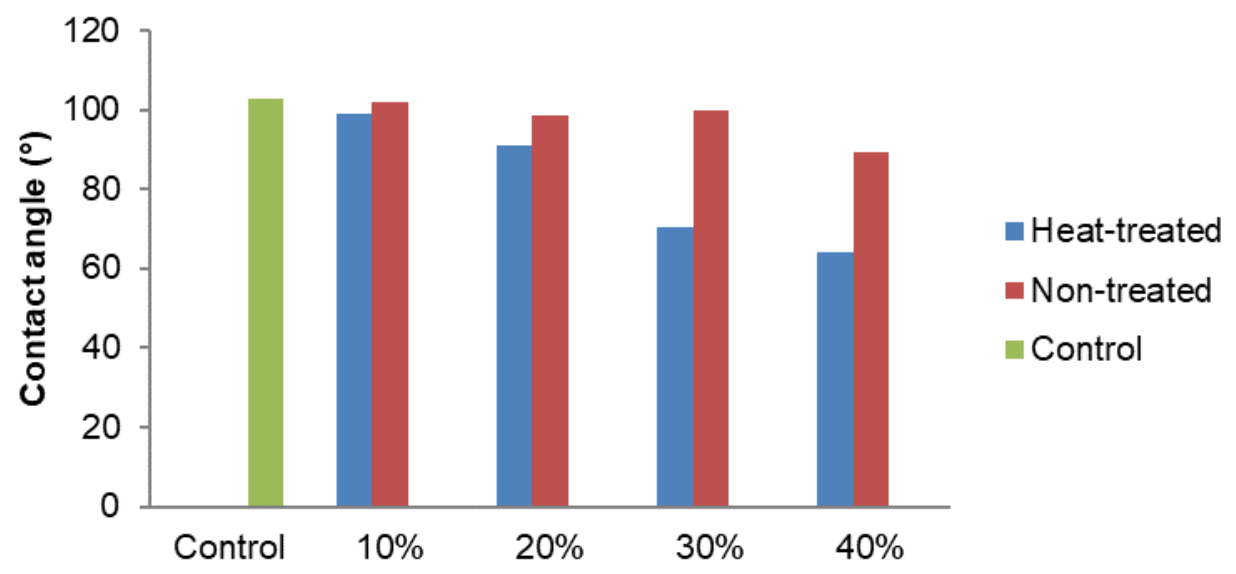

Fig. 6. CA values of the particleboards produced from HTT and NT WS particles

The control group had the highest CA value $\left(102.7^{\circ}\right)$, while the group containing $40 \%$ HTT WS particles had the lowest value $\left(64.2^{\circ}\right)$. The addition of WS to the panels significantly affected the CA values. Similar results were found by Hafezi and Hosseini (2014). They determined that the CA was reduced when the WS content in the panels increased; the exception to this was for the group containing $100 \% \mathrm{WS}$ particles. Wettability is crucial for good adhesion in bonding between particleboard and coating. When the CA is zero, perfect wetting of a surface occurs. Baharoglu et al. (2011) stated that liquids wet surfaces when the CA is less than $90^{\circ}$. The wettability of the particleboard containing HTT WS particles was improved. Although the heat treatment worsened the wettability of wood and wood-based panels (Petrissans et al. 2003; Sernek et al. 2004; Follrich et al. 2006; Gerardin et al. 2007), HTT improved the wettability of the panels containing WS particles. This may be due to the removal of the silica, non-polar 
extractives, and thin wax layer of the epidermal cell by the HTT application. In a crosssection of the WS, the epidermal cells are the outermost surface cells and are covered by a thin waxy layer. This wax layer deteriorates the moisture absorbance of straw from waterbased adhesives such as urea-formaldehyde (UF) resin (Markessini et al. 1997; Yasin et al. 2010; Hafezi and Hosseini 2014). Han et al. (2010) reported that steam explosion treatment of straw improved acidity and wettability and decreased silica content. Han et al. (1998) stated that the wettability was improved by ethanol/benzene treatment due to removal of the wax-like substance and non-polar extractives of the WS surfaces. Bekhta $e t$ al. (2018) concluded that the bonding quality of the particleboard containing WS particles could be improved by boiling.

\section{CONCLUSIONS}

1. The addition of wheat stalk (WS) particles decreased the surface roughness (SR) values and increased the water-wettability of the panels. Wettability and surface roughness of particleboard are very important when the panels are to be coated with thin overlays. The particleboards containing WS particles can be utilized for coated panels application due to improved SR and wettability.

2. Hydro-thermal treatment (HTT) and WS ratio had a statistically significant effect on the SR values and wettability of the panels.

3. The application of HTT to WS particles increased the water-wettability of the panels, however, SR values of the panels became higher.

4. The SR and contact angle (CA) values decreased when the WS ratio increased.

\section{ACKNOWLEDGMENTS}

This work was supported by Düzce University Research Fund (Project Number: 2017.02.03.550).

\section{REFERENCES CITED}

Alma, H. A., Kalaycioglu, H., Bektaş, İ. and Tutuş, A. (2005). "Properties of cotton carpel-based particleboards," Ind. Crop Prod. 22(2), 141-149. DOI: 10.1016/j.indcrop.2004.08.001

Ayrılmış, N., and Winandy, J. E. (2009). "Effects of post heat-treatment on surface characteristics and adhesive bonding performance of medium density fiberboard," Materials and Manufacturing Processes 24(5), 594-599. DOI: 10.1080/10426910902748032

Baharoglu, M., Nemli, G., Sarı B., Bardak, S., and Ayrılmış, N. (2011). "The influence of moisture content of raw material on the physical and mechanical properties, surface roughness, wettability and formaldehyde emission of particleboard composite," Composites Part B: Engineering 43(5), 2448-2457. DOI: 10.1016/j.compositesb.2011.10.020 
Bekhta, P., Korkut, S., and Hiziroglu, S. (2013). "Effect of pretreatment of raw material on properties of particleboard panels made from wheat straw," BioResources 8(3), 4766-4774. DOI: 10.15376/biores.8.3.4766-4774

Bekhta, P., Salca, E., and Kozak, R. (2018). "Properties of wood-straw composites bonded with modified UF adhesive and pre-treated straw particles," Pro Ligno 14(1), 37-41.

Bektaş, İ., Güler, C. and Kalaycioglu, H. (2002). "Manufacturing of particleboard from sunflower stalks (Helianthus annuus L.) using urea-formaldehyde resin," KSU J. Science and Engineering 5(2), 49-56. (In Turkish)

Bektaş, İ., Güler, C., Kalaycioglu, H., Mengeloglu, F., and Nacar, M. (2005). “The manufacture of particleboards using sunflower stalks (Helianthus annuus L.) and poplar wood (Populus alba L.)," J. Compos. Mater. 39(5), 467-473. DOI: $10.1177 / 0021998305047098$

Büyüksarı, Ü., Avcı, E., Ayrılmış, N., and Akkılıç, H. (2010). "Effect of pine cone ratio on the wettability and surface roughness of particleboard," BioResources 5(3), 18241833. DOI: 10.15376/BIORES.5.3.1824-1833

Candan, Z., Büyüksarı, Ü., Korkut, S., Ünsal, Ö., and Çakıcıer, N. (2012). Wettability and surface roughness of thermally modified plywood panels," Ind. Crop Prod. 36(1), 434-436. DOI: 10.1016/j.indcrop.2011.10.010

Cöpür, Y., Güler, C., Akgül, M., and Taşcioğlu, C. (2007). "Some chemical properties of hazelnut husk and its suitability for particleboard production," Build. Environ. 42, 2568-2572. DOI: 10.1016/j.buildenv.2006.07.011

Follrich, J., Muller, U., and Gindl, W. (2006). "Effects of thermal modification on the adhesion between spruce wood (Picea abies Karst.) and a thermoplastic polymer," Holz Roh-Werkst. 64, 373-376. DOI: 10.1007/s00107-006-0107-y

Gerardin, P., Petric, M., Petrissans, M., Lambert, J., and Ehrhrardt, J. J. (2007). "Evolution of wood surface free energy after heat treatment," Polym. Degrad. Stabil. 92, 653-657. DOI: 10.1016/j.polymdegradstab.2007.01.016

Grigoriou, A., Passialis, C., and Voulgradis, E. (2000). "Kenaf core and bast fiber chips as raw material in production of one-layer experimental particleboards," Holz RohWerkst. 58(4), 290-291. DOI: 10.1007/s001070050429

Güler, C., and Özen, R. (2004). "Some properties of particleboard made from cotton stalks (Gossypium hirsitum L.)," Holz Roh-Werkst. 62, 40-43. DOI: 10.1007/s00107003-0439-9

Güler, C., Bektaş, I., and Kalaycioglu, H. (2006). "The experimental particleboard manufacture from sunflower stalks (Helianthus annuus L.) and calabrian pine (Pinus brutia Ten.)," Forest Prod. J. 56(4), 56-60.

Güler, C., Cöpür, Y., and Tascioglu, C. (2008). “The manufacture of particleboards using mixture of peanut hull (Arachis hypoqaea L.) and European black pine (Pinus nigra Arnold) wood chips," Bioresource Technol. 99(8), 2893-2897. DOI: 10.1016/j.biortech.2007.06.013

Güler, G. (2019). "Thermal, burning and surface roughness properties of particleboards produced from canola (Brassica napus L.) stalks," Bilge International Journal of Science and Technology Research 3(2), 114-120. DOI: 10.30516/bilgesci.596216 (in Turkish)

Hafezi, S., and Hosseini, K.D. (2014). "Surface characteristics and physical properties of wheat straw particleboard with UF resin," J. Indian Acad. Wood Sci. 11(2), 168-173. DOI: $10.1007 / \mathrm{s} 13196-014-0136-9$ 
Han, G., Deng, J., Zhang, S., Bicho, P., and Wu, Q. (2010). "Effect of steam explosion treatment on characteristics of wheat straw," Ind. Crop Prod. 31, 28-33. DOI: 10.1016/j.indcrop.2009.08.003

Han, G., Zhang, C., Zhang, D., Umemura, K., and Kawai, S. (1998). "Upgrading of urea formaldehyde-bonded reed and wheat straw particle boards using silane coupling agents," J. Wood Sci. 44(4), 282-286. DOI: 10.1007/BF00581308

Hizıroglu, S., Hadi, Y. S., and Hermawan, D. (2008). "Surface quality of commercially manufactured particleboard panels in Indonesia," Journal of Tropical Wood Science and Technology 6, 13-16

Jarusombuti, S., Ayrilmis, N., Bauchongkol, P., and Fueangvivat, V. (2010). "Surface characteristics and overlaying properties of MDF panels made from thermally treated rubberwood fibers," BioResources 5(2), 968-978. DOI: 10.15376/biores.5.2.968-978.

Markessini, E., Roffael, E., and Rigal, L. (1997). "Panels from annual plant fibers bonded with urea-formaldehyde resins," in: Proceedings of $31^{\text {st }}$ International Particleboard/Composite Materials Symposium, Pullman, Washington, pp.147-160.

Mo, X., Cheng, E., Wang, D., and Sun, X.S. (2003). "Physical properties of mediumdensity wheat straw particleboard using different adhesives," Ind. Crop Prod. 18, $47-$ 53. DOI: 10.1016/S0926-6690(03)00032-3

Nemli, G., Kalaycioglu, H., and Alp, A. (2001). "Suitability of date palm (Phoenix dactyliferia) branches for particleboard production," Holz Roh-Werkst. 59, 411-412. DOI: $10.1007 / \mathrm{s} 00107-001-0257-\mathrm{X}$

Nemli, G., Kirci, H., Serdar, B., and Ay, N. (2003). "Suitability of kiwi (Actinidia siensis Planch) prunings for particleboard production," Ind. Crop Prod. 17(1), 39-46. DOI: 10.1016/S0926-6690(02)00057-2

Nemli, G., Ozturk, I., and Aydın, I. (2005). "Some of the parameters influencing surface roughness of particleboard," Build Environ 40, 1337-1340 DOI: 10.1016/j.buildenv.2004.12.008

Petrissans, M., Gerardin, P., El Bakali, I., and Serraj, M. (2003). "Wettability of heattreated wood," Holzforschung 57, 301-307. DOI: 10.1515/HF.2003.045

Sernek, M., Kamke, F. A., and Glasser, W. G. (2004). "Comparative analysis of inactivated wood surface," Holzforschung 58, 22-31. DOI: 10.1515/HF.2004.004

Şahin, F., Birinci, E., and Kaymakç1, A. (2018). "The effect of using rice husk in production of particleboard on surface roughness," Furniture and Wooden Material Research Journal 1(2), 103-108 (in Turkish).

Tjeerdsma, B. F., and Militz, H. (2005). "Chemical changes in hydrothermal treated wood: FTIR analysis of combined hydrothermal and dry heat-treated wood," Holz Roh-Werkst. 63, 102-111. DOI: 10.1007/s00107-004-0532-8

Turreda, L. D. (1983). "Bagasse, wood and wood-bagasse particleboards bonded with urea formaldehyde and polyvinyl acetate/isocynate adhesives," NSTA Technol. J. 8(3), 66-78.

Yalınkılıç, M.K., Imamura, Y., Takahashi, M., Kalaycioglu, H., Nemli, G., Demirci, Z., and Özdemir, T. (1998). "Biological, physical and mechanical properties of particleboard manufacture from waste tea leaves," Int. Biodeter. Biodegr. 41(1), 7584. DOI: 10.1016/S0964-8305(98)80010-3

Yasin, M., Bhutto, A.W., Bazmi, A.A., and Karim, S. (2010). "Efficient utilization of rice-wheat straw to produce value added composite products," International Journal of Chemical and Environmental Engineering 1(2), 136-143. 
Yaşar, S., Uz, A., and Beram, A. (2020). "Some properties of boards produced from heattreated brutian pine (Pinus brutia Ten.) Particles," Bilge International Journal of Science and Technology Research 4(1), 14-20. DOI: 10.30516/bilgesci.659928

Article submitted: February 17, 2020; Peer review completed: May 31, 2020; Revised version received and accepted: August 18, 2020; Published: August 21, 2020.

DOI: $10.15376 /$ biores.15.4.7648-7659 